\section{rnar an \\ APSA 2001 \\ in \\ San Francisco}

APSA will return to the City by the Bay in 2001 and we hope you will participate. The meeting will take place August 30 - September 2 at the San Francisco Hilton and Towers, Renaissance Parc 55, and Hotel Nikko.

Interested in submitting a proposal? Program Co-chairs Edward Mansfield and Richard Sisson of Ohio State are looking for a wide range of topics. The 2001 Call for Papers can be found in this issue of PS or via APSANet at www.apsanet.org.

How do your submit your proposal? Do it online via our special submission process. It's fast, easy, and reliable. Visit www.apsanet.org and look for the 2001 logo.

Don't forget, the deadline is: November 15, 2000

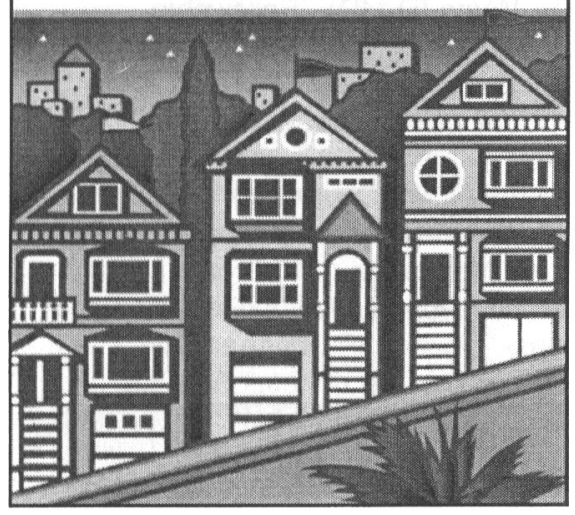

\title{
APSA Welcomes 2000-01 Congressional Fellows
}

This year's 1999-2000 class of APSA political science Congressional Fellows will leave Capitol Hill with a wealth of new contacts and future research ideas, as evidenced by Steiger Fellow Andrew Taylor's insightful article on the budget cycle in this issue of PS. In the course of their working as legislative assistants and participating in the Wilson Seminar, the Fellows have been engaged with representatives of the Office of Legislative Counsel, Congressional Budget Office, General Accounting Office, Rules Committee, committees of jurisdiction for specific legislative projects, the Congressional Research Service, and even some Executive Branch agency and departments.

A better understanding of Congress and a fuller Rolodex are not all these "hands-on" political scientists will be taking away from the fellowship. As a result of participating in a field hearing on the drug problems in Harlem, attending a fund-raising reception in Raleigh, North Carolina, discussing how the Maryland State Assembly speaker establishes a legislative agenda, observing Question Hour at the House of Commons in Ottawa, backstopping bipartisan support for a piece of legislation, or answering questions of a lobbyist on China trade legislation, they leave with the type of "war stories" likely to engage their students. Having "been there, done that" still resonates.

The teaching benefits seem to be a growing appeal of the Congressional Fellowship Program. Unlike the past few years, when newlyminted doctoral Fellows combined their Hill experience with job interviews for the following fall's academic cycle, all of the political scientists in the 2000-01 class are assistant professors. Their universities are, without exception, enthusiastic supporters of the experience.

A less-predictable benefit of being an APSA Congressional Fellow is the close contact one develops with colleagues from very different walks of life-a managing editor for a chain of 22 small Pennsylvania weekly newspapers, a journalism professor from the Texas panhandle, a Robert Wood Johnson Health Policy Fellow from Santa Fe who coordinates a network of health facilities throughout northern New Mexico, a staff officer from the Centers for Disease Control in Atlanta, an administrative appeals judge for the Social Security Administration, or a doctoral graduate from Humboldt University in Berlin. As diverse as most university campuses are today, it is unlikely that most political scientists will make such a diverse collection of close friends in the course of a single year.

The members of the 2000-2001 class of APSA Congressional Fellows are:

\section{Political Science Fellows}

Jay Barth, associate professor and chair, Hendrix College (William A. Steiger Fellow)

Amy Black, assistant professor,

Franklin \& Marshall College

Arthur Burris, assistant professor, California State University, Hayward

Brian Posler, assistant professor, Millikin University

\section{Journalism Fellows}

Christina Flint, managing editor, Montgomery Newspapers (Congressional Quarterly Fellow)

Austin Jenkins, reporter, KTVBTV7 (NBC) (Knight Foundation Fellow)

Kevin Lenihan, assistant managing editor, Courier-Observer (NY)

(Knight Foundation Fellow)

Susan Leonard, visiting professor, Texas Tech University (APSA -

MCI WorldCom Fellow)

Maria Purdy, reporter, WAFB-TV (CBS) (Knight Foundation Fellow)

\section{German Marshall Fellows}

Bertram Welker, executive assistant to the director, Aspen Institute, Berlin

Andrea Witt, Ph.D. candidate, Humboldt University, Berlin 
Edward J. Dunn, Harvard School of Public Health

Kristofer Haggllund, associate professor, University of MissouriColumbia School of Medicine

Angela Mattie, community health specialist, Corporate Medical Policy Office, Anthern Blue Cross and Blue Shield

Mario F. Pacheco, staff physician, La Familia Medical Center

Patience H. White, chair, Division of Pediatric Rheumatology, George Washington University Medical Center

\section{Federal Executive Fellows}

Carolyn P. Boyd, special assistant, Chief of Operations Branch, Department of Health and Human Services

Benjamin Brown, chief, Analysis and Planning Section, Federal Deposit Insurance Corporation

Scott Esterly, management services officer, National Security Agency

Brian Harvey, medical officer, Department of Health and Human Services

Elizabeth Hatfield, analyst and staff officer, National Security Agency

Jill S. Hood, deputy chief, Economic Policy Branch, National Security Agency

Linda B. Kalet, administrative appeals judge, Social Security Administration (Alternate)

Mary Ann Phillips, budget liaison, Social Security Administration

Bryan Rhodes, director, Modernization Plan Update, National Imagery and Mapping Agency

Eric Weinstein, state liaison for incident response, Nuclear Regulatory Commission

Sally Zeller, social insurance specialist, Social Security Administration

\section{Foreign Affairs Fellows}

Michael J. Carman, senior command representative, US-

TRANSCOM, Defense Intelligence Agency

Judith K. Demulling, intelligence advisor, Office of the Secretary of

Contributors to APSA Awards and Programs

May - July

Christopher J. Bosso

Samuel P. Huntington Henry E. Brady Sidney Verba

Robert K. Faulkner Lynn Mather

Jennifer Hochschild

Walter F. Murphy

Wilson Carey McWilliams

Howard H. Lentner

Kathleen A. Frankovic Betty Glad

Robert Y. Shapiro

George C. Edwards, III

Stephen L. Wasby

William D. Muller

Donald Tannenbaum

Leonard Champney

Harvey Glickman

Cynthia McClintock

Milton C. Cummings Jr.

Walter E. Beach

Clarence Stone

Lewis B. Sims

Robert J-P. Hauck Ken Heath

Roger H. Davidson

Charles $\mathrm{O}$. Jones

David M. O'Brien

David L. Lowery

David E. Price

Cheryl M. Miller

Allan Kornberg

Robert H. Bates

Thomas Spragens

William Mishler

Karen O'Connor

Randall Strahan

Jerome S. Legge Jr.

Loch K. Johnson

Hal G. Rainey

Michael A. Baer

Elliot E. Slotnick

Vladimir Steffel

Norman Thomas

Janet K. Boles

Leon D. Epstein

Samuel Krislov

Barbara Bardes

Lucius J. Barker

Susan Welch

Charles D. Hadley
Luis Ricardo Fraga

Robert L. Spurrier, Jr.

Dennis S Ippolito

Eugene J. Alpert

Richard W. Murray

David W. Brady

Paula D. McClain

Helen M. Ingram

F. Chris Garcia

James $Q$. Wilson

Frederic A. Bergerson

Ronald J. Schmidt

Michael B. Preston

Karen M. Hult

Daniel A. Mazmanian

Frederick Kent

Gabriel A. Almond

Richard A. Brody

Kay Lawson

J. Austin Ranney

Kenneth N. Waltz

Bruce W. Jentleson

Elizabeth F. Moulds

J. Theodore Anagnoson

Valerie J. Martinez-Ebers

David R. Mares

L. Sandy Maisel

W. Rand Smith

Tony Affigne

Thomas R. Wolanin

Gary M. Segura

Manuel Avalos

Tomoaki lwai

Jim Granato

Robert F. Durant Leslie I. Hill

W. Landis Jones

Elinor Ostrom

Thomas S. Schrock

Stanley Anderson

Jacqueline Vaughn Switzer

Charles W. Gossett

Charles L. Cotrell

Lawrence C. Dodd

Christopher Kelaher

Shawn Shieh

Gary J. Andres

Alan O. Ebenstein

John W. Caldwell

Jurg Martin Gabriel

Mary R. Hamilton

Catherine Edwards

Nicole Burgess

John W. Cotton 


\section{The American Political Science Association announces the 2001-02}

\section{Congressional Fellowship Program}

WHO: Early and mid-career political scientists.

WHY: To learn more about the legislative process through direct participation.

HOW: A comprehensive three-week orientation period; full-time assignments as legislative aides in the House of Representatives and/or Senate; seminar program with leading congressional, governmental and academic figures.

QUALIFICATIONS: A scholarly interest in Congress and the policymaking process; a Ph.D. completed within the last fiffëen years (or near completion). Applicants who are not current residents of the United States must be able to fund their own transportation to Washington to be interviewed should they be selected as finalists.

THE FELLOWSHIP YEAR: Orientation begins November 2001; office assignments run December 2001 through August 15, 2002.

STIPEND: $\$ 35,000$, plus travel allowance.

APPLICATION PROCEDURE: Submit eight copies each of:

- a detailed curriculum vitae;

- a personal statement (about 500 words) explaining how the Congressional Fellowship Program relates to your professional goals;

- a sample of your best writing (one published or unpublished manuscript). Submit, also, the names of three professional references who have agreed to write letters of recommendation.

REFERENCES: Candidates are responsible। for arranging that the letters of recommendation arrive in our offices by December 15, 2000.

\section{APPLICATION DEADLINE:}

December 1, 2000; mail to Director, Congressional Fellowship Program, American Political Science Association, 1527 New Hampshire Avenue, NW, Washington, DC 20036.

Awards will be announced by April 2001. 
Defense, Defense Intelligence

Agency

Marjorie G. Fitton, senior operational program manager, National

Reconnaissance Office

Charles F. Hunter, Levant desk officer, Department of State

Russell P. Ingraham, NATO desk

officer, Department of State

Jodi B. Lieberman, international

relations officer, Nuclear Regulatory

Commission

Indra Niles, budget officer, $\mathrm{Na}$ -

tional Reconnaissance Office

Jinnett M. Rona, chief, Operation-

al Target Analysis Branch, Central

Intelligence Agency

Tonya P. Wilkerson, resource operations coordinator, Central Intelligence Agency

\section{Section News}

\section{Public Policy}

Professor Kenneth Bickers, department of political science, Indiana University, has been appointed editor of Policy Currents. The newsletter will be based at the IU Workshop on Political Theory and Policy Analysis. Further information will be forthcoming in the next issue. Ken Bickers can be reached at kbickers@indiana.edu.

\section{Foreign Policy}

By vote of its members, and in order to fully reflect the interests of its members, Domestic Sources of Foreign Policy has changed its name to just Foreign Policy.

\section{Washington Insider}

\section{Faculty Express Satisfaction with their Career Choices}

Ninety percent of full-time faculty at two- and four-year institutions were satisfied with their career choices, according to a nationwide survey of 15,111 faculty members conducted in 1999 by the University of Chicago's National Opinion Research Center. The American Faculty Poll found the high level of job satisfaction even though $40 \%$ of faculty members considered leaving academia at some point in their careers due to low salaries, a depressed job market, or politics within their departments or institutions. Not surprisingly, tenured faculty were more satisfied with their careers than were faculty still on the tenure track. However, faculty at institutions without tenure were more satisfied than their tenured colleagues. Copies of the report sponsored by TIAA-CREF are available from Voon Chin Phua, TIAA-CREF, 730 Third Ave., 21 st Floor, New York, New York 10017-3206; vcphua@tiaa-cref.org.

\section{Doctoral Students Shift Their Focus in the Job Market}

Doctoral students prefer tenure-track appointment, but are more willing than new faculty members to consider nontenure-track jobs, and jobs at a broader range of institutions, so finds The Faculty Recruitment Study. The survey was conducted in early 2000 by the Project on Faculty Appointments at Harvard University. The two major conditions that sway doctoral student's willingness to take nontenured positions are geographic location and the balance between teaching and research. Doctoral students are also casting a wider net in their job search than new faculty. Only $12 \%$ of students said they expected to apply to only research institutions, in contrast with $74 \%$ of faculty who reported having applied to research universities. Among students, $94 \%$ planned to apply to comprehensive state colleges, $57 \%$ to liberal arts colleges, and $47 \%$ to community colleges. Faculty tended, however, to have a narrow job search with only $37 \%$ reporting they had applied to liberal arts colleges, $29 \%$ to comprehensive state colleges, and 5\% to community colleges. Additional information from The Faculty Recruitment Study is available online at www.hpfa.org.

\section{Commerce Department Proposes to Empower Census Director}

On June 20, the Commerce Department issued a proposed rule that would give the Director of the Census Bureau final authority over whether to release data adjusted through sampling. The rule will go into effect after a 45-day comment period. Secretary William Daly issued the proposed rule before leaving to head the Gore presidential campaign in response to a "Statement on the Feasibility of Using Statistical Methods to Improve the Accuracy of Census 2000", prepared by Census Bureau Director Kenneth Prewitt. The director's commitment to statistically-adjusted or sampled numbers to gain greater accuracy is not shared by some members of Congress. During hearings of the House Subcommittee on the Census on June 22, Subcommittee Chair Representative Dan Miller (R-FL) challenged the merits and legality of the rule change. Miller questioned whether the Census Bureau Director, himself a political appointee, might not use the proposed delegated power to manipulate census data for partisan purposes. Prewitt affirmed that he was interested in producing the most accurate census not in influencing the outcomes of state and federal elections.

\section{NSF Celebrates 50th Anniversary, Promises More Funds for Social and Behavior Sciences}

The National Science Foundation celebrated its 50th anniversary on May 10, 2000. Looking forward to the twenty-first Century, NSF Director Rita Colwell called the Social, Behavioral and Economic Sciences Directorate "one of the most important directorates of NSF in the next 20 years and beyond." Addressing the Advisory Committee to NSF's SBE, Colwell again voiced her commitment to a major initiative for the SBE directorate in the Foundations's FY2003 budget. Norman Bradburn, assistant director of SBE, announced the appointment of Miron Staf, former director of the Committee for National Statistics at the National Academy of Sciences, to coordinate the proposed initiative.

Colwell emphasized that the contributions of NSF-supported research are not widely recognized, a point driven home by the House appropriations subcommittee's reluctance to fund the proposed $17.3 \%$ increase in the NSF FY2001 budget, recommending a $4.3 \%$ increase instead. Currently, all discussions of the NSF budget have been suspended.

While reluctant to increase resources to NSF, members of the House Appropriations Committee, echoed their Senate colleagues and urged agencies to increase funding for social and behavioral sciences. The commitment to acquiring greater understanding of how and why people behave the way they do was reflected in the committee-approved allocation of \$125 million for a National Campaign to Change Children's Health Behaviors. 